UDC 069:355(477) «1910/1920»

DOI: $10.24919 / 2519-058 x .7 .130660$

Vadym MASHTALIR, orcid.org/0000-0002-8132-217X

Ph D hab. (History), Chief of Department - Deputy Head of Department of the Main Department of Personnel of the General Staff of the Armed Forces of Ukraine

(Ukraine,Kiev)vadim_mashtalir@ukr.net

\title{
A HISTORICAL WAY OF THE UKRAINIAN STATE MILITARY MUSEUM (1917 - 1920)
}

The article is devoted to the analysis of the activities of the Ukrainian state military museum during 1917 - 1920. The author considers and highlights the prerequisites for the creation, functioning, achievements, and destiny of the specified museum in the specified chronological frames.

The activity of the museum, materials, and documents covering the work of the museum and its figures - A. D. Blahodir and M. Y. Obidnyi, have been analyzed, namely, the definition of the main ideas of these statesmen to improve the museum work of Ukrainian military historical institutions on the example of the state military museum. The activity of the military museum was investigated during the influence of state power in the period between the domination of the territory of Ukraine by the authorities of the Central Rada and Soviet Russia and the arrival of Bolshevik troops to Kiev.

The origins of the concept for the collection of historical material and scientific activity of the military historical museum are revealed. The author established that the period of the Ukrainian liberation movement became a time of the cultural revival of the Ukrainian people when certain advances in the museum sphere were achieved.

In a complex military-political situation, scientific and public memorial conservation organizations, together with state institutions established during the Ukrainian revolution, focused on protecting and preserving monuments of Ukraine's military history. But at the same time, the research of museum items and collections, the holding of exposition works did not have a planned character, they were conducted selectively because in the complex military and political conditions the main task of the Ukrainian state military museum was to preserve the monuments from destruction and robbery.

The author notifies, that the activity of the museum was to collect and protect the monuments of the revolution, much attention was paid to preserving the monuments of antiquity on the ground, saving archives, in particular the archive of the First world war, valuable documents and materials of the Kiev department of the Russian military historical society. In the era of the Hetmanate, the Ministry of Public Education and Arts provided financial assistance to the museum institution, and the left part of the Mariinsky Palace was allocated for the placement of the exhibition. In the summer of 1918, the museum suffered a tragic fate, when due to a misunderstanding between officials of different ranks over the museum collections an act of vandalism was committed.

According to the results of archival materials of the Central state archives of the supreme bodies of power and government in Ukraine (F. 3179, Op. 1, 16 cases), which occupies the period 1919 1922 and the personal fund in the archives of M. Y. Obidny (F. 3504, Op. 1, 12 cases) established that M. Obidny, after the termination of the Ukrainian military historical museum, in 1920 created a new museum education - the Main military historical museum-archive at the General Staff of the Ukrainian People's Republic.

Key words: exhibit, expedition, museum-archive, military-historical museum. 
Вадим МАШТАЛІР,

кандидат історичних наук, начальник відділу - заступник начальника управління Головного управління персоналу Генерального штабу Збройних Сил України (Україна, Kиїв) vadim_mashtalir@ukr.net

\section{ІСТОРИЧНИЙ ШЛЯХ УКРАЇНСЬКОГО ДЕРЖАВНОГО ВІЙСЬКОВОГО МУЗЕЮ (1917 - 1920 РОКИ)}

Стаття присвячена аналізу діяльності Украйнського держсавного військового музею протягом 1917 - 1920 рр. У статті висвітлено передумови створення, функиіонування, здобутки та долю зазначеного музею. Проаналізовано діяльність музею, матеріали і документи, щзо висвітлювали роботу музею та його діячів - О. Д. Благодіра та М. Ю. Обідного, а саме визначенню основних ідей иих державних діячів щодо поліпшення музейної роботи украйнських воєнно-історичних установ на прикладі державного військового музею. Досліджено діяльність музею під час впливу державної влади у період між пануванням на території Украӥни Центральної Ради та Радянської Росії і приходом, слідом за иим, більшовицьких військ до Києва. Розкрито зародження концепчії зі збору історичного матеріалу та наукової діяльності військово-історичного музею.

Ключові слова: експонат, експедиція, музей-архів, військово-історичний музей.

Problem statement. The Ukrainian revolution of 1917 - 1921 gave a significant impetus to the state-forming processes in Ukraine. Inextricably linked with the tasks of state and cultural construction, the issues of protection and preservation of the national military historical heritage were resolved (Denysenko, 2014: 36-42).

Military museums are a multi-vector and unique historical source, both in its content and in the form of interpretations of information, a means of informing society, since they unite around themselves the true admirers of the military historical past.

The Ukrainian military history museum (or the Ukrainian State military museum) is a cultural institution that was established in 1917 on the basis of the military history museum of the Kiev branch of the Russian imperial military historical society. The post of director in this museum since May 1917 was occupied by the official Alexander Demyanovich Blagodir - a native of the Kiev province, former director of the historical archive in the city of Smolensk. Assistant to the director of the museum was a native of Poltava region - an official Mikhail Yuryevich Obidny (TSDAVO. F. 1075. Content 2. Case 37. Sheet. 201-204).

The functioning of this military museum occurred during the period of military seizure of state power in Ukraine, its short-term rule and another sharp change in the period between the rule of the Central Rada and Soviet Russia and the arrival after that in Kiev bolsheviks.

Analysis of research. The activities and results of the work of the Ukrainian state military museum found their first coverage in 1918 on the pages of the Military Scientific Bulletin of the General Staff (MHM, 1918: 70-71) and in 1919 on the pages of the Military military Journal (MMJ, 1919: 54), as well as in the articles A. Blagodir «Ukrainian kleynods» (Blagodir, 1918: 58-65), «From the martyrology of Ukrainian antiquity» (Blagodir, 1919: 1-2) and M. Obidny «Military-Scientific Expeditions» (Obidny, 1919: 69).

The regional critic and art critic F. Ernst in 1918 described the tragic fate of the Ukrainian State Military Museum in an article entitled «Arts Treasures of Kiev that suffered in 1918» when an act of vandalism was committed as a result of a misunderstanding between officials of different ranks over museum collections (Ernst, 1918: 20). 
In the Ukrainian scientific literature, scientist O. Denysenko in the article «Public Initiatives for the protection of monuments of history and culture in the Ukrainian State of 1918» (Denysenko, 2014: 36-42), considers the activity and historical path of the Ukrainian military historical museum in the context of research of initiatives of public institutions and state institutions on the analysis of shifts in the cultural life of the Ukrainian State of 1918.

The main body of sources on the history of the Ukrainian revolution is concentrated in the Central state archives of the highest bodies of power and government of Ukraine. Founded in 1921 as the Central archive of the revolution, it had a special purpose - to store documents on the history of the revolutionary movement and the central state institutions of the post-imperial period.

Given such thematic orientation, its foundations focus on authentic documents on the history of the creation and functioning of major state entities - the Ukrainian People's Republic of the time of the Central Rada, the Ukrainian State (Hetmanate), the Ukrainian People's Republic of the period of the Directory, the Western Ukrainian National Republic, the Ukrainian Socialist Soviet Republic, their central and regional governments.

Thus, in the Central state archives of the supreme bodies of power and administration in Ukraine, there is a fund (F. 3179. Content 1. 16 cases), that covers the period $1919-1922$ and the personal fund of M. Y. Obidny (F. 3504. Content 1. 12 cases). However, the Ukrainian historiography does not have a generalized complex scientific work on the activities of the above-mentioned military historical museum.

The purpose of the article is to highlight the preconditions for the creation, functioning, achievements, and destiny of the museum in the specified chronological frames, as well as a description of the museum's concept, which was first proposed by the Ukrainian State Military Museum for the collection of historical material and scientific activities.

Presentation of the main material. The Public Committee for the commemoration of the soldiers who perished during the First World War operated in Kyiv (Denysenko, 2014: 36-42). It consisted of state and public figures, members of the city duma, well-known artists. On November 15,1915 , it was decided to perpetuate the heroes who died on the fronts of the First World War and announced a competition for the creation of projects of temples, chapels, and monuments to establish them in the field of battles and military cemeteries.

In June 1916, after summarizing the results of the competition, the construction of a temple in Kiev began, which was to become the main object of the memorial complex of the military cemetery for officers and soldiers who died at the fronts and died from wounds in Kiev hospitals. Construction began in the area of the military cemetery (Zverinetska street), but it could not be completed. The Public committee that dealt with these issues through the revolutionary events ceased its activities (Isakova, 1991: 57).

It should be noted that a large role in the protection of monuments of military history was played by museums around which the accomplices of the memorial case were united, who made considerable efforts in Kyiv to organize the National archives museum of war and revolution.

In August 1917, with the initiative of its creation, the cultural-educational commission of the All-Ukrainian Council of Military Deputies made a statement that, through the press, appealed to the public to send exhibits to the future museum that would characterize the development of revolutionary events in Ukraine (Nova Rada, 1917).

This proposal was supported by the department of preservation of monuments of antiquity and art of the government. The plan for the creation of this museum was developed in September 1917. The work on the implementation of the developed plan for the creation of a new museum has begun. 
In the spring of 1918, after the unification of the Museum of war and revolution 1914 1917, established in 1917, and the Military historical museum of the Kiev division of the Russian military historical society in Kyiv, the Ukrainian State military museum was created (Denysenko, 2014: 36-42).

Exhibits for the new archive-museum of war and revolution were selected at the Kiev artillery warehouse, as well as in other cities of Ukraine. By creating a museum of war and revolution, the All-Ukrainian Council of military deputies appealed to the chief of staff of the Kyiv military district to hand over to the museum some of the exhibits of the military historical museum. However, assistance from the military leadership was not received (Mashtalir, 2012: 194-211).

Obviously, with the onset of a war between the Central Rada and Soviet Russia and the arrival of the bolshevik troops in Kyiv, the activity of the museum was stopped. However, it is known that during the time of the bolshevik authorities in Kyiv, a «guard sheet» was issued to the museum's leadership and its collections remained intact (Ernst, 1918: 20).

Restoration of the work of the Ukrainian military historical museum in

Kiev was held in March 1918 - after the liberation of the city by parts of the Central Rada and German troops. On April 1, an order was issued by the Military Ministry of the Ukrainian people's Republic part 13 (for General Staff), which ordered: «All military units, institutions and institutions that are within Ukraine and subject to disbandment for demobilization, immediately send to the military science department of the General the headquarters of the Ukrainian People's Republic (11, Bankova street, Kyiv), descriptions and precise information on the status and location of flags, letters of commendation, icons and generally valuable historical documents and things: paintings and portraits, collections of weapons, signs of clothing and supplies, as well as libraries».

According to the order, all these things should be transferred to the State Ukrainian Military historical museum or the Library of the General Staff (MSB GSt, 1918: 53).

Detailed information on the activities of the Ukrainian state military museum in AprilJune 1918 was published on the pages of the «Military Scientific Bulletin of the General Staff», which was published in Kiev. In part 2 of this edition (released in late April), an article entitled «Military Historical Notes» was published, probably attributed to Blagodir (the material was published without a signature), in which the concept of a museum was actually presented (MSB GSt, 1918: 53).

During the Hetmanate time, the Ministry of education and the arts has provided the museum with financial assistance, and the left wing of the Mariinsky Palace in Kyiv has been allocated for the placement of the exhibition. The article states that the new institution of culture is created on the model of the Berlin military museum in the left wing of the Royal Palace.

It «will serve the purpose of raising the population's love and respect for the native army, protecting the native land and introducing the people, especially the school youth (excursions of the students from the explanation of the museum's director) with the latest news of military equipment. For this purpose, it is planned to publish catalogs with illustrative photographs for sale at the lowest price to all those who enter the museum and send them free of charge to schools, arrange an exhibition of military weapons, uniforms, and weapons, photographs, and drawings from the theater of military events, etc» (MHN, 1918: 44).

According to the plan of the founders of the museum, he was supposed to consist of the following departments: a) the era before the Mongol-Tatar invasion (Scythian-Sarmatian and Slavic era); b) the Polish-Lithuanian era; c) the time of the Hetmanate; d) the period from Hetman Mazepa to the reign of Paul I; e) «recent times» - until 1914; f) The First World War. 
For the exposition, it was planned to order models of ships and airplanes of various designs of that time. A special commission was to be sent to the places of battles of the First world war and the armed struggle for the Ukrainian People's Republic (hereinafter - UPR) - to collect the exhibits. A special platform with samples of military equipment was to be built in front of the museum building: cannons, machine guns, bombs, mortars, various technical military equipment, and model trenches with wire obstacles.

The author listed the achievements of the museum as of April 1918:

1. The banner of the Bogdanovsky regiment (1917) with the inscription «The 1st Ukrainian Cossack named after Hetman Bogdan Khmelnitsky regiment» was received from the General Staff;

2. The regimental flag of the 160th infantry Abkhazian regiment of the Russian army;

3. Portrait of General judge of the Hetmanate times Gamalei brought from home Gamall in Konotop district;

4. Portrait of Hetman Ivan Mazepa, probably acquired from private individuals (MHN, 1918: 44).

The third issue of the Military Scientific Bulletin (MSB GSt, 1918: 53), which was published in the second half of May 1918, was published articles by the director of the museum A. Blagodir «State Military Historical Museum» and his deputy M. Obidny «Military-scientific expeditions». In the article A. Blagodir (it was signed only with the letter «B.»), it was a question of new acquisitions to the museum, these were (MHM, 1918: 70-71):

a) thirteen regimental banners of the Russian regiments that were kept in the premises of the First Ukrainian Military School (before - the Kiev Grand Duke Konstantin Konstantinovich military school);

b) six flags, two silver pipes and regimental folding of various parts of the Russian army, sent to the museum by organizations and individuals.

The article by M. Obidny is, in fact, a concept for collecting the unique material and scientific activity of the military historical museum. It was suggested:

1. Transfer all exhibits of a military nature from other museums, and if they are not transportable - take photos;

2. Publish «appeals» to citizens about free admission (or redemption for money) of exhibits;

3. To immortalize the places where the glorious military events took place, especially the location of the Zaporizhzhya Sich, the corresponding monuments, and to draw up short historical chronicles about them;

4. Restore the old graves and pour new ones - where the Cossack leaders were buried;

5. Take photos of iconic military buildings;

6. Create an album of drawings of Ukrainian military relics;

7. Make notes about all the historical military relics, which are on the territory of Ukraine and outside (M. Obidny, 1918: 69).

In the development of the concept outlined in M. Obidny's article «Military scientific expeditions», in the next issue of the «Military scientific bulletin», A. Blagodir's essay «Ukrainian Kleinody» (Blagodir, 1918: 58-65) was published. It briefly mentioned some Ukrainian military relics, especially the Zaporizhzhya Sich era, which were stored outside the homeland - in the museums of Petrograd and Moscow, and also in Ukraine, in particular, in the museums of Odessa (Blagodir, 1918: 58-65).

Thus, the activity of the museum was to collect and protect the monuments of the revolution, much attention was paid to preserving the monuments of antiquity on the ground, saving archives, 
in particular, the archive of the First world war, valuable documents and materials of the Kiev department of the Russian military historical society (Denysenko, 2014: 40).

On the night of June 22 to June 23, 1918, the activities of the museum and its leadership were interrupted in the most unexpected way, and the museum suffered a tragic fate, when, due to a misunderstanding between officials of different ranks, an act of vandalism was committed over museum collections. After the director of the museum A. Blagodir refused to vacate the premises for the needs of the Military ministry, armed officers broke into the museum premises and began to throw valuable exhibits on the street where they fell under the rain.

The events that occurred were covered in detail in the book of the famous local historian Fyodor Ernst:

«Meanwhile, the palace is occupied by the Ministry of Internal Affairs; the huge building, probably, appears to be tight, and now the head of the Military historical museum receives an order to immediately clean the premises for the needs of the said ministry. In vain asked the head of the department to preliminarily withdraw another building, at least somewhat suitable for the needs of the museum. June 17 follows the categorical order of the military ministry to "take out the museum property on the square».

The headmaster was forced to report that «as an expert in the matter and the true son of Ukraine ... throwing an extremely valuable museum on the street with my own hands, I have no legal and moral right. And on June 22, at 11 o'clock in the morning, a detachment of soldiers led by the chief of the military science department of the General Staff, despite protests and resistance to the administration of the museum, began to take out the museum property to the square in front of the outbuilding. Some of the things were thrown into the windows. In the morning there was a huge downpour.

As a result, paintings and drawings were soaked, weapons, ancient chain mail, armor - rusted, regimental banners and banners were damaged, several busts were broken, many windows were destroyed, a lot of weapons were stolen. At present, the spoiled remains of a valuable museum are dumped in the dirty and damp basement of the General Staff building. The head of the museum, for failure to comply with the orders of the authorities, is deprived of a post» (Ernst, 1918: 20).

A. Blagodir was dismissed, and the remains of the exhibits were moved to a private house in Kiev at the address: St. Catherine, 12, which became the «house of the museum». In February 1919, after the arrival of the Red Army in Kiev, the military historical museum was preserved and, according to available information, remained under the control of the Soviet military department - the reconstructed headquarters of the Kiev military district. Approximately in March-April 1919 in the «house of the military historical museum» from the district headquarters on street Bankova moved to the editorial office of the Military-Military Journal, an organ of the Kiev's military district (MMJ, 1919: 50).

The actions of the military to liberate the premises of the left wing of the Mariinsky Palace, which occupied the museum, aroused indignation on the part of the broad scientific and cultural community. A sharp assessment was received about the circumstances of the destruction of the Military museum at a meeting of the Cultural Commission at the Ukrainian Peace Delegation. The adopted resolution noted that such acts not only harm national and cultural construction in Ukraine but also undermine its authority in the international arena (Ernst, 1918: 19-20).

The well-known public and cultural figure M. Bilyashivsky categorically evaluated the actions of the military department in a letter to Colonel Arkas, who, on behalf of the staff, investigated the incident (Denysenko, 2014: 40-41). The head of the department for the protection of monuments of art and art wrote in a letter of June 29, 1918: «At a time when there is a lot of 
talk about protection and the acquisition of monuments, which we have kept very little, a ready museum, carefully collected, barbarously destroyed. It was impossible to assume that such a thing could have happened among even a non-cultural citizenship» (NAHM FIAS. F. 13. Content 5. Case 308. Sheet 3).

July 3, 1918, this terrible act was the subject of discussion at a meeting of the Council of Ministers of the Ukrainian State. And although for the performers who deliberately destroyed the monuments of Ukrainian history, everything ended almost without any consequences, this event became an occasion for solving pressing problems in the field of museum construction and protection of monuments of work in general. This concerned the provision of museum facilities with appropriate facilities, the training of personnel for museum institutions and, in general, the implementation of measures for the protection of monuments in the center and in the field. (Denysenko, 2014: 40-41).

The further fate of the exhibits of the Ukrainian military historical museum was as follows. In January 1919, before the retreat of the acting army of the Ukrainian People's Republic from Kiev, the flag of the 1st Ukrainian Cossack Regiment named Bohdan Khmelnitsky and some other regalia associated with the struggle with the bolsheviks. The rest of the exhibits remained in the city. In the autumn of 1919, when Kiev was under the authority of the Armed Forces of South Russia (the white guard troops of general A. Denikin), the vast majority of the regimental flags and other relics of the Russian Imperial Army was removed from the museum. Later (in the 1920s) these relics became the basis of the collection of Russian military flags that were exhibited at the Belgrade Church in Yugoslavia. After the entry into the territory of Yugoslavia of the Red Army, a collection of flags was transported to the museums of Leningrad and Moscow. As for the works of culture, art, furniture, historical things, etc., they mostly became the property of Soviet museums in Kyiv in the 1920's (Tinchenko, 2013: 48).

Due to constant military actions and instability of political power in 1920 - 1940, the work of military-historical institutions in the territory of Ukraine was destroyed. In early February 1919 troops of the Ukrainian People's Republic left Kyiv. Despite the fact that a considerable amount of museum exhibits has remained in the city, its management, as well as probably some valuable things and documents, left Kiev. The director of the museum was again A. Blagodir (TSDAVO. F. 3504. Content 1. Case 1. Sheet 1-150).

He was a staunch opponent of the power of Hetman P. Skoropadsky. After the troops of the Directory on December 14, 1918, occupied Kiev, Blagodir became the head of the commission for manning the Main Directorate of the General Staff of the Ukrainian People's Republic. On December 25, a meeting of this commission took place, at which it was decided to release 18 people - generals, chiefs, and officials, «so that they would not be accepted by any department of our Republic, as people, who are hostile to the cause of the Ukrainian People» (CDAWOW. F. 1508s / 3779, Content 1. Case 1. Sheet 52-71).

A large part of 1919, the Directorate of the Ukrainian military historical museum located in the city of Kamyanets-Podilsky. A. Blagodir and his unchanged deputy M. Obidny at that time were considered in the staff of the Main Directorate of the General Staff of the Ukrainian People's Republic (TSDAVO. F. 1075. Content 2. Case 37. Sheet 201-204).

In the autumn of 1919 with the participation of Blagodir A. D., the first and only issue of the magazine «Ukrainian antiquities» was published. It begins with the article of Alexander Demyanovich «From the martyrology of Ukrainian antiquities». The author described the history of the robbery of Ukrainian antiquities. He remembered that during the time of the Russian Empire, 
the finds that were made on the Ukrainian lands were mass exported to the museums of St. Petersburg and Moscow.

During the First World War, Russian troops expropriated and exported to Russia the collections of L'viv Stauropigy. During the Bolshevik rule, a mass sale of antiquities began both from state museums and private collections. Many rarities were bought for almost nothing to cost by representatives of foreign missions. Blagodir has critically evaluated the activities of the Hetman's government: for the confiscating the premises of the military historical museum in Kiev and the maritime museum - in Mykolaiv (Blagodir, 1919: 1-2). Incidentally, the mention of confiscation of the premises of the maritime museum in Mykolaiv is still the only evidence of attempts to create a similar institution of culture.

Summarizing the above, it is possible to note that from November 1919 Kamyanets-Podilsky became the arena of the struggle between Ukrainian, White Guard, Polish, and later - the Red Army. The activities of the administration of the Ukrainian Military History Museum were finally discontinued. According to some information, A. Blagodir went to L'viv. His deputy, M. Obidny, in 1920 created the Main Military Historical Museum-Archive at the General Staff of the Ukrainian People's Republic. But this was already a new museum creation.

Conclusions. The period of the Ukrainian liberation movement can be characterized as a period of time relative to the cultural revival of the Ukrainian people when certain advances in the field of military museology were achieved. In a complex military and political situation, leading scientists of the time and public figures, together with the Ukrainian military historical museum, focused on the protection and preservation of monuments of military history.

It's a shame to admit that during the period under review the registration and accounting of the museum exhibits of the Ukrainian military historical museum were episodic and selective, and, basically, this was due to the unstable political situation in Ukraine, as well as, as evidenced by archival materials, insufficient funding. At the same time, according to the author of the article, the main value of the work and the high evaluation of the activity of the military historical museum in difficult military and political conditions is the preservation of authentic monuments of military history from destruction and robbery.

We will consider that this scientific investigation is only a basis for continuing research on the development of military museology, and its practical significance consists in the possibility of using the revealed factual material, its scientific interpretation, and conclusions regarding the formation and functioning of military historical museums on the territory of Ukraine.

\section{BIBLIOGRAPHY}

Благодір, 1918 - Благодір О. Українські клейноди / Військово-науковий вісник Генерального Штабу. 1918 р. Київ, ч. 4-5. С. 58-65.

Благодір, 1919 - Благодір О. 3 мартирольогії української старовини / Благодір // Українська старовина. Орган Комісії для охорони пам'яток старовини та мистецтва при Головнім управлінні мистецтв і національної культури. 1919. № 1. С. 1-2.

ВВЖ, 1919 - Военный-військовий журнал. Київ. 1919. №3. С. 50.

ВІ3, 1918 - Військово-історичні замітки / Військово-науковий вісник Генерального штабу, 1918 р. Київ. Ч. 2. С. 44.

ВНВ ГШ, 1918 - Військово-науковий вісник Генерального штабу. 1918 р. Київ. Ч. 2. С. 53.

ДВІМ, 1918 - Б. Державний Військово-Історичний Музей / Військово-науковий вістник Генерального штабу. 1918 р. Київ. Ч. 3. С. 70-71.

Денисенко, 2014 - Денисенко О. А. Громадські ініціативи з охорони пам'яток історії та культури в Українській Державі 1918 р. // Наукові записки. Том 156. Історичні науки. 2014. С. 36-42. 
Исакова, 1991 - Исакова Е. В. Храмы-памятники русской воинской доблести. М., 1991. С. 57. Машталір, 2012 - Машталір В. В. Розвиток музейної справи в системі Міністерства оборони України // Збірник наукових праць «Праці Центру пам'яткознавства». Київ: Центр пам'якознавства НАНУ і УТОПИК. 2012. Вип. № 22. С. 194-211.

НАФРФ ІМФЕ (Національні архівні фонди рукописів та фонозаписів Інституту мистецтвознавства, фольклористики та етнології ім. М. Рильського НАН України).

Нова Рада, 1917 - Нова Рада. 1917. 20 серпня.

Обідний, 1918 - Обідний М. Військово-наукові експедиції // Військово-Науковий вісник Генерального Штабу. 1918 р. Київ. Ч. 3. С. 69.

Тинченко, 2013 - Тинченко Я. Старый Цейхгауз // Русские полковые знамена в фондах Национального музея истории Украины. Москва. 2013. №1. С. 48.

ЦДАВОУ - Центральний державний архів вищих органів влади та управління України.

Эрнст, 1918 - Эрнст Ф. Художественные сокровища Киева, пострадавшие в 1918 году. Киев. 1918. $20 \mathrm{c}$.

\section{REFERENCES}

Blahodir, 1918 - Blahodir O. Ukrainski kleinody [Ukrainian jewelry] / Viiskovo-naukovyi visnyk Heneralnoho Shtabu, 1918 r. Kyiv. Ch. 4-5. Pp. 58-65. [in Ukrainian]

Blahodir, 1919 - Blahodir O. Z martyrolohii ukrainskoi starovyny [Martirolog Ukrainian antiquity] // Ukrainska starovyna. Orhan Komisii dlia okhorony pam'iatok starovyny ta mystetstva pry Holovnim upravlinni mystetstv i natsionalnoi kultury. 1919. № 1. Pp. 1-2. [in Ukrainian]

VVZh, 1919 - Voennyj-viiskovyi zhurnal, Kyiv. 1919. № 3. P. 50. [in Ukrainian]

VIZ, 1918 - Viiskovo-istorychni zamitky / Viiskovo-naukovyi visnyk Heneralnoho shtabu. $1918 \mathrm{r}$. Kyiv. Ch. 2. P. 44. [in Ukrainian]

VNV HSh, 1918 - Viiskovo-naukovyi visnyk Heneralnoho shtabu, 1918 r. Kyiv. Ch. 2. P. 53. [in Ukrainian]

DVIM, 1918 - B. Derzhavnyi Viiskovo-Istorychnyi Muzei / Viiskovo-naukovyi vistnyk Heneralnoho shtabu. 1918 r. Kyiv. Ch. 3. Pp. 70-71. [in Ukrainian]

Denysenko, 2014 - Denysenko O. A. Hromadski initsiatyvy z okhorony pam'iatok istorii ta kultury v Ukrainskii Derzhavi 1918 r. [Public initiatives for the protection of historical and cultural monuments in the Ukrainian State 1918] // Naukovi zapysky. Tom 156. Istorychni nauky. 2014. Pp. 36-42. [in Ukrainian]

Ysakova, 1991 - Ysakova E. V. Hramy-pamiatnyky russkoi voynskoi doblesty [Churchesmonuments to Russian military valor]. M. 1991. P. 57. [in Russian]

Mashtalir, 2012 - Mashtalir V. V. Rozvytok muzeinoi spravy v systemi Ministerstva oborony Ukrainy [Development of Museum business in the system of the Ministry of defense of Ukraine] // Zbirnyk naukovykh prats «Pratsi Tsentru pam'iatkoznavstva». Kyiv: Tsentr pam'iakoznavstva NANU i UTOPYK. 2012. Vyp. № 22. Pp. 194-211. [in Ukrainian]

NAFRF IMFE (Natsionalni arkhivni fondy rukopysiv ta fonozapysiv Instytutu mystetstvoznavstva, folklorystyky ta etnolohii im. M. Rylskoho NAN Ukrainy) [NAFRF IMF (National Archives of Manuscripts and Phonographies of the Institute of Art Studies, Folklore Studies and Ethnology named after M. Rylsky, NAS of Ukraine)]

Nova Rada, 1917 - Nova Rada. 1917. 20 serpnia. [in Ukrainian]

Obidny, 1918 - Obidny M. Viiskovo-naukovi ekspedytsii [Military-scientific expedition] // Viiskovo-Naukovyi visnyk Heneralnoho Shtabu, 1918 r. Kyiv. Ch. 3. P. 69. [in Ukrainian]

Tynchenko, 2013 - Tynchenko Ya. Staryj Tseikhhauz [Old Zeughaus] // Russkie polkovye znamena $\mathrm{v}$ fondah Nacional'nogo muzeya istorii Ukrainy. Moskva. 2013. №1. P. 48. [in Ukrainian]

TsDAVOU - Tsentralnyi derzhavnyi arkhiv vyshchykh organiv vlady ta upravlinnya Ukrainy [Central State Archive of the Higher Authorities and Administration of Ukraine] EHrnst, 1918 EHrnst F. Hudozhestvennye sokrovishcha Kieva, postradavshie v 1918 godu [Kyiv Artistic treasures, suffered in 1918], Kyev, 1918. 20 p. [in Russian]

Стаття надійшла до редакиїі 18.04.2018 p. 